\title{
Solidarity as a Practical Reason: Grounding the Authority of International Law
}

\author{
Kostiantyn Gorobets ${ }^{1}$
}

Accepted: 27 January 2022 / Published online: 28 February 2022

(c) The Author(s) 2022

\begin{abstract}
This article discusses the concept and the principle of solidarity in international law. It is often argued that solidarity is a(n) (emerging) principle of international law, yet its normative function in international law is not clear or well defined. I trace the development of the idea of solidarity and show how its image gradually shifted from reflecting the factual societal bonds to being mainly normative and thus functioning as a reason for action. In international legal scholarship, solidarity is often portrayed as a principle of international law, but there is a great deal of variety in which normative ideas we label as 'principles'. There are several groups of 'principles of international law' that are very different in the type of the normative function they perform in or for international law. I investigate to which of these groups solidarity belongs and what can it tell us about its role in international law. I suggest that solidarity is a kind of normative principle, which, though essential for the legitimation of international law, is not legally normative by the function it performs. I draw a line between having a normative function within and outside the law, and use the concept of pre-emptive reasons to show why solidarity is not and should not be considered as a principle of international law in order to perform the normative function that it has. I argue that the authority of international law requires that normative ideals such as solidarity are pre-empted, and therefore replaced in practical reasoning, by legal rules.
\end{abstract}

Keywords Solidarity $\cdot$ Legal principles $\cdot$ Principles of international law $\cdot$ Authority of international law $\cdot$ Pre-emption $\cdot$ Legal normativity

This article was presented at ESIL Research Forum 'Solidarity: The Quest for Finding Utopias of International Law' (Catania, 20-21 April 2021). I thank all the participants of the Forum for their invaluable comments and questions. Special thanks go to the anonymous reviewer of the ESIL Paper Series, as well as the anonymous reviewers of the Netherlands International Law Review for their many suggestions and comments.

Kostiantyn Gorobets

k.v.gorobets@rug.nl

1 University of Groningen, Groningen, The Netherlands 


\section{Introduction}

What does acting on the basis of solidarity imply? What kind of practical considerations are involved when some actor (be that a person, a social group, or a political entity such as a state) claims that she acts in a certain way out of solidarity? More importantly, what does it mean when we say that (international) law is grounded on, or structured by, the principle of solidarity? These questions are not only central to any attempt to justify a specific normative content of international law in the domains of environmental protection, climate change, international trade and development, etc. They may also relate to theoretical investigations into the nature and authority of international law, as well as its societal grounds.

Solidarity itself may be understood very differently and its meaning often depends on the particular context of its use, and for this reason it is difficult to comprehensively define it. In fact, it is much easier to explain what solidarity means by elaborating on its particular manifestations, be that an emotional sense of the unity of social groups and classes (e.g., when solidarity is discussed in the context of revolutions and social movements), a moral obligation to provide mutual assistance (e.g. solidarity as social co-dependence and cooperation), or a one-sided duty to help those in need (e.g., solidarity with refugees or victims of social injustice). This makes solidarity a very nebulous concept, with risks that one instance of its use may not at all fit another.

Things become even trickier when solidarity is discussed in the context of the global community, in particular, as a matter of international law. In contemporary international law, solidarity occupies a peculiar position. On the one hand, it is one of the most important ideals that legitimise international law, alongside justice, peace, prosperity, sustainability, etc. The promotion of solidarity is then a moral duty for states and other international actors, just like the promotion of other values of universal significance. When viewed as such, in international legal arguments there is no need to claim that peoples and states ought to show solidarity with other peoples and states. It is a moral duty, and moral duties, as is known, though they may be reinforced by law, do not depend thereon. On the other hand, the idea of solidarity is often depicted as a principle of international law. From this perspective, there is something more to solidarity than just a moral value. If it is a principle of international law, states and other subjects of international law not merely ought to act out of solidarity as a matter of moral duty, but they must do so as a matter of law.

As I will show, despite (or perhaps thanks to) the ambiguous normative and legal status of solidarity in international law, it is common to treat it as marking the features of the contemporary era of international law. We now live in an age of solidarity, as slogans go, and although it may sound rather too optimistic, there is certainly some truth in this. States and peoples are becoming increasingly interdependent, which shapes the relations between them so that there is more and more value in cooperation than there used to be. This makes the idea of solidarity even somewhat more mysterious; is there something more normatively robust behind it than the political and moral pathos that are used to legitimise international law? How is solidarity reflected in the authority structure of international law? 
This paper aims to discuss the issue of what normative status the principle of solidarity has in international law. I am not trying to unpack the meaning of solidarity in international law, nor do I focus on how this idea is manifested in different areas of international law (although these issues cannot be altogether avoided). Rather, I wish to explore what normative implications the idea of solidarity creates, especially in the context of a tendency to represent solidarity as a principle of international law. I will do so by relying primarily on analytical jurisprudential methodology, rather than on doctrinal or normative analysis, and thus this paper is primarily an exercise in legal philosophy, which also explains why I primarily rely on sources in analytical jurisprudence. This also dictates the structure of this paper. I start with a brief overview of how solidarity has come to be viewed as a principle of international law and what debates surround this view (Sect. 2). I then turn to exploring what kind of 'principle' solidarity is, considering that we use the concept of legal principles very differently depending on the context (Sect. 3). I try to show why it is essential to differentiate between principles which are legally normative, and those which, though essential for law, are not. In Sect. 4, I discuss the function of legality and why moral and political principles require legal pre-emption. This allows me to discuss how solidarity grounds, together with similar moral and political concepts, the normative authority of international law. My ultimate aim is to show that solidarity is not and should not be considered a principle of international law in order to perform the normative function that it has.

\section{Solidarity and International Law: A Path from Fact to Principle}

Without doubt, solidarity is one of the most important normative ideas driving the development of today's international law. The spirit of solidarity pierces many regimes of international law and leaves its marks in many international legal instruments; it inspires international legal regulation and is used to argue further developments in international law. The aim of this section is to trace, in a rather sketchy manner, that intellectual history of solidarity which made it such an influential idea. By doing so, I want to investigate those conceptual foundations that underlie the popular concept that solidarity is a principle of international law.

The concept of solidarity, especially in its connection to international law, has a long and rich history. Starting with writings by the 'founding fathers of international law', the idea of a community as underlying any notion of international normativity necessarily relied on a shared commitment to jus gentium, which is seen by many as a precursor to today's understanding of solidarity. ${ }^{1}$ But most notably since the peak of its popularity in social, political, and legal philosophy in the first decades of

\footnotetext{
1 E.g., Vincente Marotta Rangel offers an interesting account of Vittoria's take on solidarity as related to universitas christiana in Rangel (2012). A more comprehensive analysis by Camilo Barcia Trelles (1927) shows Vitoria as having contributed the seeds of ideas which germinated as the theory of international solidarity. Hedley Bull, Benedict Kingsbury, and Adam Roberts (1992, p. 8) claim, in their analysis of Grotius from a solidarist perspective, that 'solidarist principles are [...] clearly discernible in Grotius' writings, and they may be seen as an implicit concomitant of most early concepts of international society'.
} 
the twentieth century, solidarity has become one of the most influential of concepts. 'There exists a social solidarity which comes from a certain number of states of conscience which are common to all the members of the same society', ${ }^{2}$ wrote Émile Durkheim, laying the groundwork for solidarism. The great sociologist believed that the more complex society becomes, 'the more, consequently, social cohesion derives completely from this source [i.e. solidarity] and bears its mark' ${ }^{3}$ Léon Duguit, who was probably the most renowned solidarist of his generation, shared this view, but also believed that social solidarity has a normative aspect, too. This normative side of solidarity translates into the most important social rule (which he called 'objective law') that 'impl[ies] that everyone has the social obligation to fulfil a certain mission and the power to perform the acts required for the accomplishment of this mission'. 4

Georges Scelle, another influential solidarist, supposed that the factual bounds between people form 'a factual solidarity, constituted by an interest or a bulk of interests common to the members of the group, interests which are often vital and which can only be satisfied by the existence of the group. ${ }^{5}$ The fact that common interests and interdependencies exist between people suggests a normative proposition that they should act out of solidarity with each other. This normative manifestation of solidarity, according to Scelle, is most apparent when it is converted into specific rules and becomes the law of a society. As a result, positive law is a mere translation of social solidarity: "the normative aspect of the legal order is for us just a formulation of the social fact or of the phenomenon of inherent solidarity. ${ }^{6}$

This peculiar factual/normative dualism of solidarity has also marked its use in international legal scholarship. Solidarity acquired the status of one of the critical intellectual 'building blocks' of international legal theory since Alejandro Alvarez's works in the early twentieth century. International law, according to Alvarez, is nothing but a 'regime of solidarity' constructed through international relations, the codification of international law, and other forms of legal cooperation. ${ }^{7}$ Moreover, 'this notion of solidarity', wrote Alvarez, '[...] is of paramount importance for international law. It must guide its future

\footnotetext{
${ }^{2}$ Durkheim (1933), p. 109. First published in 1893, this book inspired most political and legal studies on solidarity.

${ }^{3}$ Ibid., p. 109.

${ }^{4}$ Duguit (1908), p. 12. 'Droit objectif, impliquant pour chacun l'obligation social de remplir une certaine mission et le pouvoir de faire les actes qu'exige l'accomplication de cette mission.' Unless indicated otherwise, translations from French are mine.

${ }^{5}$ Scelle (1935), p. 42. '[...] une solidarité de fait, constituée par un intérêt ou un faisceau d'intérêts communs aux membres du groupe, intérêts souvent vitaux et qui ne peuvent être satisfaits que par l'existence du groupement'.

${ }^{6}$ Ibid., p. 45. 'La partie normative de l'ordre juridique n'est pour nous que la formulation du fait social ou du phénomène de solidarité originaire.'
}

${ }^{7}$ Alvarez (1912), pp. 59-62. 
orientation, at the same time as providing objective elements for its interpretation; well understood it will give it the prestige it deserves'. ${ }^{8}$ Alvarez believed that solidarity is the new factual state of international affairs which should replace the outdated factual state of complete sovereign independence, ${ }^{9}$ and at the same time it is the fundamental normative driving force of such a replacement, a drive towards internationalism. ${ }^{10}$

This line of reasoning, that international solidarity is something coming to replace the old factual structure of international relations and thereby altering international law as well, determined the influence of this idea in international legal scholarship. For instance, Bruno Simma stresses that community interests, which caused the booming institutionalisation of international law in the postWorld War II era, 'go far beyond interests held by States as such; rather, they correspond to the needs, hopes and fears of all human beings, and attempt to cope with problems the solution of which may be decisive for the survival of entire humankind'. ${ }^{11}$ Community interests, Simma believes, reshape the traditional structure of international law as a thin legal order comprising primarily bilateral relations, which resonates with Alvarez's view on solidarity as a driver of the further development of international law. Karel Wellens takes this idea a step further by distinguishing three paradigms of international law, which he calls 'the law of coexistence', 'the law of cooperation', and 'the law of solidarity'. International law, Wellens believes, has gradually moved from embodying the mere coexistence of states to providing grounds for their cooperation. The next step for international law should then be solidarity, and 'the law of solidarity will influence the respective and combined role and impact of the two pre-existing approaches to international law'. ${ }^{12}$

Solidarity, then, has the feature of being both factual and normative, reflecting social interdependencies and at the same time embodying the basic social rule. Remarkably, most contemporary reflections on solidarity in (international) legal scholarship and social philosophy tend to focus more on its normative side. More importantly, when solidarity is taken normatively, it is sometimes depicted as a legal concept, not just generally as a social or moral one. When Léon Duguit wrote that solidarity embodies the most important social rule, he also insisted that this rule is a legal one:

this social rule of conduct is not a moral rule, but a rule of law. It only applies to external manifestations of human will; it does not impose itself on the inner

\footnotetext{
${ }^{8}$ Ibid., p. 128. 'Cette notion de solidarité est [...] d'une importance capitale pour le droit international. Elle doit guider son orientation future, en même temps que fournir des éléments objectifs d'interprétation; bien comprise elle lui donnera le prestige qui lui revient'.

9 Ibid., p. 30. 'La notion de solidarité a [...] remplacé l'ancienne conception de l'indépendance et de la souveraineté absolue.'

${ }^{10}$ Ibid., p. 32. '[...] internationalisme, s'il est conduit de façon à ne pas étouffer le sentiment national patriotique, peut être une cause de rénovation du monde'.

11 Simma (1994), p. 244.

12 Wellens (2005), p. 804.
} 
man; it is the rule of his external acts, and not that of his thoughts and his desires, which on the contrary must be any moral rule. ${ }^{13}$

That solidarity has been seen as having such a genealogy is owed to the idea that it is 'the legal-political form for the emotionally loaded but somewhat disreputable revolutionary idea of "fraternity". ${ }^{14}$ Whereas fraternity has an explicit moral and even passionate flavour to it, solidarity has been seen as a more rational and, very importantly, legally embedded concept. ${ }^{15}$ Solidarity is thus intellectually shaped as an intrinsically legal and political idea, as something born within law, rather than brought into it from the moral domain.

This has had its impact on the international legal conceptualisations of solidarity, too. Today's international law and scholarship fully embrace the idea that solidarity is a powerful legitimising ideal lying within the foundation of modern international law. It is also almost never questioned that solidarity is amongst the most important principles, generally speaking. The growing interdependence between states gives the idea of solidarity probably an even more forceful spin than the nineteenth century's industrialisation, which brought it to life in the first place. This makes cooperation one of the central tasks which states ought to perform. ${ }^{16}$ But the principle of solidarity, as many scholars believe, and to whom I now turn, forms the basis for such cooperation and makes it possible for states to engage in coordinating global action to begin with. However, it is far more than just that; solidarity is sometimes seen not just as any principle, but as a principle of international law.

To begin with, Rüdiger Wolfrum - one of the leading authorities on the issue of solidarity in international law-claims that solidarity belongs to the "principles having their origin directly in international legal relations', and this shapes its status as a 'structural principle of international law' ${ }^{17} \mathrm{He}$ also states that solidarity has a threefold function in international law: 'the achievement of common objectives through

\footnotetext{
13 Duguit (1908), p. 9 (emphasis added). 'Cette règle social de conduite n'est point une règle de morale, mais bien une règle de droit. Elle ne s'applique qu'aux manifestations extérieures de la volonté humaine; elle ne s'impose point à l'homme intérieur; elle est la règle de ses actes extérieurs, et non pas celle de ses pensées et de ses désirs, ce que doit être au contraire toute règle de morale.'

14 Koskenniemi (2002b), pp. 288-301. Jack Hayward writes: 'In the late nineteenth and early twentieth century, for the abstract principles of liberty, equality and fraternity was substituted the eclectic notion of solidarity,' which was deemed as 'more scientific'. Hayward (1961), pp. 20, 27.

15 Which might seem plausible, since, originally, solidarity was an exclusively legal concept that related to obligations on collective debts and could be traced back to Roman law, where 'each member of [a family] was held responsible for the payment of the whole of the debt contracted by any member, and had the right to receive payment of debts owed to the collectivity'. Hayward (1959), p. 270.

16 'States have the duty to co-operate with one another, irrespective of the differences in their political, economic and social systems, in the various spheres of international relations, in order to maintain international peace and security and to promote international economic stability and progress, the general welfare of nations and international co-operation free from discrimination based on such differences'. Declaration on Principles of International Law concerning Friendly Relations and Co-operation among States in accordance with the Charter of the United Nations, UNGA Res. 2625 (XXV) (24 October 1970).

17 Wolfrum (2009), p. 9.
} 
common actions of States, the achievement of common objectives through differentiated obligations of States and actions to benefit particular States' ${ }^{18}$

Ronald MacDonald shares a similar sentiment towards solidarity. In his influential article, he stresses that solidarity is a special mode of cooperation, an ideological glue that brings together efforts to achieve a common good. He emphasises that solidarity is not merely relevant for international law, but has an explicit legal normative role to play:

Solidarity is first and foremost a principle of cooperation which identifies as the goal of joint and separate state action an outcome that benefits all states or at least does not gravely interfere with the interests of other states. Solidarity, as a principle of international law, creates a context for meaningful cooperation that goes beyond the concept of a global welfare state; on the legal plane it reflects and reinforces the broader idea of a word community of interdependent states. ${ }^{19}$

Abdul Koroma writes not only that solidarity grounds international law structurally, but is also capable of generating obligations for states:

solidarity in current international law represents [...] an emerging structural principle which in many cases creates negative obligations on States not to engage in certain activities, and in an increasing number of contexts establishes concrete duties on States to carry out certain measures for the common good. $^{20}$

Markus Kotzur shares a similar position when investigating the idea of solidarity in EU law: 'solidarity as a legal principle has to be distinguished in a negative and a positive component. Negative solidarity is seen as mere response to certain dangers or events, whereas positive solidarity creates, consequent upon previous negative notion, joint rights and obligations'. ${ }^{21}$

Rüdiger Wolfrum, however, believes that solidarity might not have enough of a normative impact to generate positive obligations for states, but it may be said to create negative obligations: "states that refrain from acceding to regimes which are meant to protect the interests of the international community, are under an obligation not to undermine such efforts'. ${ }^{22}$

The idea that solidarity is an emerging (or) structural principle of international law is often demonstrated by references to particular legal regimes. Scholars trace solidarity in international economic law and international environmental law ${ }^{23}$; add to this the international legal regime of collective security, ${ }^{24}$ international law on

\footnotetext{
18 Ibid., p. 8.

19 MacDonald (1996), pp. 259-260 (emphasis added).

${ }^{20}$ Koroma (2012), p. 103.

21 Kotzur (2017), p. 40.

22 Wolfrum (2013), p. 417.

23 MacDonald (1996).

24 Slaughter (2005).
} 
climate change, ${ }^{25}$ international humanitarian law and international law on human rights, ${ }^{26}$ international refugee law, international law on disaster relief, and the law of state responsibility. ${ }^{27}$ Solidarity is also often discussed in the context of the doctrine of the responsibility to protect, ${ }^{28}$ and sometimes even in relation to international criminal law. ${ }^{29}$ These different manifestations of solidarity arguably show that solidarity is not only a principle of international law, but even that it has constitutional status within the international legal order. This latter claim is most visible in Karel Wellens' statement that:

The principle of solidarity may rightfully claim constitutional status because of the high degree of constitutionalisation it has acquired within the UN law on the maintenance of international peace and security, because it is increasingly ensuring the cohesion and consistency of international legal order across various branches and because it operates with regard to both primary and secondary rules. ${ }^{30}$

Solidarity, then, is often seen as being a principle of international law, and its relevance and status are shown through a variety of manifestations in different legal regimes and branches of international law. At the same time, the principle of solidarity is conceptualised as a normative construct that has a direct or indirect impact on states' rights and obligations. Solidarity, then, 'imposes joint obligations on States to address international problems, ${ }^{31}$ and in this role it also informs how states must cooperate 'for the purposes of development to increase the social welfare of the world community'. ${ }^{32}$

There are, however, other views on solidarity in international law. Many international lawyers label solidarity merely as an aspirational concept, or as a tool for a moral legitimation of international law. It can therefore be said that there is no consensus on whether solidarity can be characterised as one of the structural principles of international law, or whether it has become a legal principle in international law. ${ }^{33}$ Thus, Jost Delbrück insists that solidarity does not generate any legal obligation to cooperate, ${ }^{34}$ whereas Theo van Boven expresses a similar concern in respect of the right to peace as being generated from solidarity. ${ }^{35}$ Danio Campanelli even writes that.

\footnotetext{
25 Williams (2009).

26 Rangel (2012); Wellman (2000); Wolfrum (2013).

27 Koskenniemi (2002a).

28 Koroma (2012); Tzimas (2019); Wolfrum (2009) pp. 17-19.

29 Nyst (2012).

30 Wellens (2010), p. 36 (emphasis added).

31 Koroma (2012), p. 109.

32 Wolfrum (2010b).

33 See, e.g., Kojima and Menzel (2009).

34 Delbrück (2012), pp. 15-16.

35 van Boven (2011).
} 
It would be hardly sustainable that solidarity is today a fully acknowledged legal principle governing international law and from which it would be possible to draw a clear set of duties and obligations for international subjects. On the other hand, the concept of solidarity [...] permeates certain legal discourses in the international law sphere, where it appears to be something more than mere cooperation or reciprocity. ${ }^{36}$

Even more so, Rüdiger Wolfrum-one of the main advocates of solidarity as a principle of international law-wrote that the principle of solidarity is not a kind of legal principle from which concrete rights and obligations are deduced, but which can serve as a tool for interpreting certain regimes of international law as well as an instrument for its progressive development. ${ }^{37}$ And Karel Wellens, while defending the constitutional status of solidarity in international law, at the very same time stated that he 'did not actually say [...] that the principle of solidarity is a legally binding principle'. 38

We are confronted with an intriguing question, then. Regardless of whether solidarity is legally binding or not, is it reasonable to call it a principle of international law? Is it necessary or desirable that solidarity, by having a normative role in international law, must qualify as a legal principle in order to perform this role? We have traced the evolution of the normative side of solidarity up to these questions, and what follows will be devoted to answering them.

\section{Solidarity as a Matter of Principle}

Is solidarity a principle of international law? Should it be or will it become one in the future? If it is a (structural) principle of international law, what kind of obligations does it generate? These debates which surround the concept of solidarity in international legal scholarship reflect one of the most important jurisprudential problems. This problem, which to a significant degree shaped contemporary legal philosophy, pertains to the issue of principles and their function in law. What I mean here is not the question which is often discussed in international legal scholarship in relation to 'the general principles of law recognized by civilized nations,' that is, whether or not general principles belong to sources of international law, ${ }^{39}$ and if so, how they can be identified. This particular theoretical puzzle is of little relevance for the inquiry undertaken here. Instead, the focus of this section is on what place principles such as solidarity have within international legal normativity. This focus

\footnotetext{
36 Campanelli (2011).

37 Wolfrum (2010a), pp. 225-228.

38 Wolfrum and Kojima (2010), p. 93 (quote from the comments section of the book).

39 See, generally, Brownlie (2008); Cheng (2006); Gaja (2013); Thirlway (2019).
} 
is indeed very much anchored in the jurisprudential debates around principles and their role in law, ${ }^{40}$ but goes beyond them. ${ }^{41}$

One of the main problems with the concepts of 'legal principles', 'principles of law', or 'general principles of law' is that we use them to label very distinct phenomena, not all of which are even legal, and this often creates confusion. For this reason, not everything that looks like a principle of international law is, in fact, a principle of international law or a principle of international law. That is, not everything that can be labelled as a legal principle has in fact a normative function in international law or even beyond it. It is essential, therefore, to clarify what kind of 'principle of international law' solidarity is, considering that the use of this concept is not at all uniform. If we were to summarise all the different kinds of phenomena we call 'legal principles' or 'principles of law' ${ }^{42}$ in international law, this is more or less what we would get: ${ }^{43}$

1. 'legal principles' that are, in fact, ordinary legal rules, to which we attach more argumentative weight by labelling them as principles;

2. 'legal principles' that establish legal standards of behaviour but, however, do not stipulate any specific actions to be taken by those to whom they apply;

3. 'legal principles' that, although relevant for law, are not, in fact, legal principles through the function they perform; rather, they represent certain political or moral norms or ideals which legitimise international law;

4. 'legal principles' that are not norms generally speaking, but moral values which the law is supposed to appreciate and protect.

Some caveats have to be mentioned before I proceed. First, I do not imply that there is always a clear-cut distinction between these categories, and sometimes, depending on the context, 'principles' may migrate between them. This, however, as far as I can tell, does not challenge the analytical accuracy of the distinction. Second, as I will elaborate further, there are several other dividing lines here. For instance, I believe that the first two categories of 'principles' are legal, whereas the latter two are not and should not be. I will discuss this issue in the next section. Finally, these distinctions between various 'types' of legal principles have more to do with

\footnotetext{
${ }^{40}$ I mean, of course, the Hart-Dworkin debate, which sparked an important discussion within analytical jurisprudence about what kind of function legal principles perform. See, generally, Dworkin (1977); Dworkin (1986); Hart (1994); Raz (1972); Shapiro (1998); Shapiro (2007).

41 Thus, I am not discussing one of the core issues pertaining to the conundrum of principles, that is the status of judicial discretion. This debate is of less relevance for international law, where the judiciary has a far more limited impact on law than in domestic legal systems.

42 I use quotation marks here and further to differentiate between the concept of a legal principle (no quotation marks) and its use in different contexts (with quotation marks). I do this, as will be clear later, because not all 'legal principles' are in fact legal principles.

43 In the discussion that follows, I limit myself to only the instance of a normative use of the concept of a principle. That is, I am not discussing other possible connotations of the term, like, for instance, when it is used descriptively to refer to some body of rules without specifying the exact content of those rules (for instance, 'principles of international trade law', or'principles of international criminal law'). As nicely put by Joseph Raz, such use of the concept of a principle is very similar to how we use acronyms, that is, as shortcuts that refer to some phenomena, but which do not have any meaning of their own. Raz (1972), pp. 828-829.
} 
jurisprudential concerns than with those having a doctrinal nature. ${ }^{44}$ This is why the analysis that follows by and large does not overlap with (and so also does not challenge) the ILC's codification efforts led by Marcelo Vázquez-Bermúdez, the Special Rapporteur on general principles of law. ${ }^{45}$ At the same time, the categories identified above reflect the multifaceted nature of legal principle as also stressed in the First Report by the Special Rapporteur:

general principles of law, in addition to serving as a direct source of rights and obligations, may serve as a means to interpret other rules of international law or as a tool to reinforce legal reasoning. A more abstract role is sometimes attributed to them, such as that they inform or underlie the international legal system, or that they serve to reinforce its systemic nature. ${ }^{46}$

Returning to the four categories of 'principles of international law' outlined above, to which of them may the principle of solidarity belong? Let us investigate them one by one. The first category is a tricky one. It is common to speak of, for instance, the principle of the prohibition of genocide, ${ }^{47}$ or the principle of non-intervention, ${ }^{48}$ or the principle of the non-use of force in international relations. ${ }^{49}$ What unites all of these is that they are not principles at all, but ordinary legal rules; perhaps some of the most important and vital for the international community, but still regular legal rules. This distinction is one of the critical ones, famously conceptualised by Ronald Dworkin: rules that govern behaviour act in an all-or-nothing fashion (e.g., if there is a prohibition on some action, it is either prohibited or not, there are no inbetweens), whereas principles have a dimension of weight and because of this do

\footnotetext{
${ }_{44}$ I mean by this that my inquiry here does not aim to resolve any particular issue related to a proper interpretation or application of international law. Nor do I try to provide an insight on the specific normative relations between rules and principles of international law in a particular domain or regime. Instead, I am looking at solidarity and principles of international law through analytical lenses and ask questions that have to do primarily with the nature of (international) law, its normativity and authority.

45 See ILC, 'Report of the International Law Commission on the work of its seventy-first session', (29 April-7 June and 8 July-9 August 2019) UN Doc. A/74/10, paras. 202-262.

46 ILC', First report on general principles of law of the Special Rapporteur, Mr. Marcelo Vázquez-Bermúdez', UN Doc. A/CN.4/732, para. 26 (footnotes omitted).

47 'The principles underlying the Convention [on the Prevention and Punishment of the Crime of Genocide] are principles which are recognized by civilized nations as binding on States, even without any conventional obligation.' Reservations to the Convention on the Prevention and Punishment of the Crime of Genocide (Advisory Opinion) (1951) ICJ Reports 15, p. 23. As the UN Office on Genocide Prevention and the Responsibility to Protect puts it, '[States] are all bound as a matter of law by the principle that genocide is a crime prohibited under international law.' 'Genocide', UN Office on Genocide Prevention and the Responsibility to Protect, accessed February 20, 2020, https://www.un.org/en/genocideprevent ion/genocide.shtml. Accessed 13 December 2021.

48 'The principle of non-intervention involves the right of every sovereign State to conduct its affairs without outside interference.' Military and Paramilitary Activities in and against Nicaragua (Nicaragua v. United States of America) (Merits) (1986) ICJ Reports 14, para. 202. See also Jamnejad and Wood (2009).

49 In Armed Activities, the ICJ established that 'the Republic of Uganda [...] violated the principle of non-use of force in international relations'. Case Concerning Armed Activities on the Territory of the Congo (Democratic Republic of the Congo v. Uganda) (Merits) (2005) ICJ Reports 168, para. 345(1). See also Kreß et al. (2015).
} 
not stipulate a concrete outcome when applied. ${ }^{50}$ As Joseph Raz phrases this distinction, 'rules prescribe relatively specific acts; principles prescribe highly unspecific action'. 51 There is nothing unspecific or not stipulating a concrete outcome in the given examples. States are under very definite and rather specific obligations not to intervene in the internal affairs of other states, not to commit genocide, and not to use force in international relations. That these may be subjects of fierce debate as to what counts as genocide, or what counts as an intervention, or what counts as a use of force, does not infringe upon the fact that these are very specific acts. There is nothing in these legal obligations that indicates that they are logically different from any other customary or conventional legal obligation that states have. So here the concept of a 'principle' is used in a rhetorical manner rather than in any other.

It is not difficult to see that the principle of solidarity does not quite fit here. To begin with, solidarity does not actually prescribe any specific normative standard for states' actions. It is exactly why scholars are having such difficulty in trying to elaborate on what exactly the principle of solidarity requires states to do. From this perspective, there is very little in common between the principle of solidarity and, for instance, the principle of the non-use of force, apart from both being often called 'principles of international law'. Whereas the latter renders a specific mandatory prohibitive legal rule, the former is but an inspirational ideal, or as Robert Alexy calls it, an 'optimization command' that 'something be realized to the highest degree that is actually and legally possible'. 52

The second category, which comprises 'legal principles' that typically prescribe highly unspecific legal standards of behaviour, but which are nevertheless legally binding, includes principles like, for instance, the principle of the freedom of the high seas, ${ }^{53}$ the principle of the freedom of maritime communication, ${ }^{54}$ the principle of proportionality, ${ }^{55}$ the principle of due diligence, ${ }^{56}$ and many others. These principles do not direct states to perform any specific actions; rather, they provide for a normative standard from which legal obligations may be deduced in specific circumstances. In other words, even though such principles are in themselves highly unspecific in the character of the actions they prescribe, they are nevertheless legally binding. What also unites these principles is that they have other normative functions in law, apart from guiding the actions of states and other subjects. Principles such as these are often used for the purposes of interpreting legal rules by offering the justificatory reasons or ratio legalis underlying legal rules; they may also provide grounds for modifying existing rules and establishing particular exceptions to

\footnotetext{
50 Dworkin (1977).

51 Raz (1972), p. 838.

52 Alexy (2000), p. 300.

53 See, e.g., Bouchez (1973).

54 Corfu Channel Case (UK v. Albania) (Merits) (1949) ICJ Reports 4, p. 22.

55 See, generally, Cottier et al. (2017).

56 See, e.g., Barnidge (2006).
} 
legal rules, or allow non liquet situations to be avoided by providing, in such a way, the grounds for new rules. ${ }^{57}$

Does solidarity fit this category? As we saw in the previous section, it is not at all obvious that solidarity is a legally binding principle. Even the most dedicated advocates of solidarity as a principle of international law tend to agree that it does not directly generate legal obligations. And this makes all the difference here, for the principles in this category are legally binding. Not acting on the basis of solidarity in, say, disaster relief, and not acting on the basis of proportionality, for instance, in the context of applying countermeasures, may have drastically different legal qualifications and consequences. When violating the principle of proportionality may in itself lead to the qualification of an act as legally wrongful, ${ }^{58}$ there can hardly be any legal consequences for violating the principle of solidarity.

We are now left with the last two categories. As already mentioned, unlike the previous two categories, these two comprise 'legal principles' which are not necessarily legal, and this may cause a great deal of confusion as to where to draw the line between law and non-law. This was essentially the main claim by Ronald Dworkin, who brought the issue of principles into the core of jurisprudence: since we often apply moral or political principles to justify a legal position, positivists' insistence on a clear-cut separation between law and non-law does not hold true. ${ }^{59}$ In the context of my investigation here, things are complicated by the unclear normative status of solidarity. Let us take a general look at both categories before returning to solidarity.

The third category - 'principles of international law' which are in fact not legal principles at all-hides some pitfalls. It is common, in international law as well, to encounter principles that create no direct legal normative implications, that is, no legal duties can be deduced from them. They neither prescribe a certain line of behaviour, nor establish anything that can even weakly be called a legal obligation. Rather than prescribing, they are describing a normative order to which they belong and outline its essential features. Jeremy Waldron calls them 'characterising principles', as they 'tell us what a legal system is like, not how to work within it' ${ }^{60}$ These are principles such as federalism, popular sovereignty, limited government, separation of powers, etc., to give examples, following Waldron, from the constitutional law of the US. In international law, there are also such characterising principles, for

\footnotetext{
57 As Jean d'Aspremont argues, this latter function of legal principles is the original one when it comes to international law. Moreover, that principles perform this function makes it incoherent to treat them as a source of international law. d'Aspremont (2018). See also, on the function of legal principles in international law, Bassiouni (1990).

58 As indicated by the ILC in the commentary to Art. 51 of the Draft Articles on Responsibility of States for Internationally Wrongful Acts, 'Proportionality provides a measure of assurance inasmuch as disproportionate countermeasures could give rise to responsibility on the part of the State taking such measures.' ILC, 'Draft Articles on Responsibility of States for Internationally Wrongful Acts', Yearbook of the International Law Commission, 2001, vol. II, Part Two, p. 134. Notably, the ILC speaks of proportionality as a rule, rather than as a principle. This is another indication of how much uncertainty exists around this concept.

59 Dworkin (1977).

60 Waldron (2019).
} 
instance, the principle of sovereign equality, or the principle of self-determination of peoples, or the principle of good faith.

These principles are very different from those which we analysed before. Normative principles, such as proportionality or due diligence, guide actions by establishing a legal standard of behaviour (no matter how abstractly or vaguely). Characterising principles are different in this regard. They certainly perform a normative function politically, for they guide the construction of normative orders and legitimise them by reference to political and moral considerations. The problem begins when we try to establish whether they have any normative function legally, i.e. whether we can say that they have a normative impact on the legal arguments being used within an existing normative system. Jeremy Waldron argues that they do not. ${ }^{61}$ Rather, they shape constitutional systems by reflecting certain political and philosophical designs, but they are no more normative for legal issues than the bearing walls of a building are for the choice of room decorations. To say that a constitutional system is based on the principle of the separation of powers is to describe certain aspects of this system by pointing out a particular feature of its institutional design. It is quite difficult to specify legal obligations that stem from this principle and legally bind some or all of the subjects of this legal order. ${ }^{62}$

The final fourth category of phenomena which we at times call 'legal principles' or 'principles of law' comprises certain moral values that law embodies or is supposed to protect. Here, many examples can be given. In Corfu Channel, the ICJ referred to the general principle of 'elementary considerations of humanity, 63 which definitely reflects moral values that international law protects. In international human rights law, it is not at all atypical to speak of the principle of (respect for) human dignity, ${ }^{64}$ whereas in international humanitarian law, the principle of humanity is considered to be one of the most fundamental. ${ }^{65}$ In international environmental law, it is common to speak about the principle of intergenerational equity, ${ }^{66}$ while in

\footnotetext{
61 'It is only legal normativity that is the problem. That a $\mathrm{CP}$ [characterising principle] may be politically and philosophically normative is something we can take for granted.' Waldron (2019), p. 27.

62 The same goes, for instance, for the principle of good faith, which, according to the ICJ, is 'one of the basic principles governing the creation and performance of legal obligations, [but which] is not in itself a source of obligation where none would otherwise exist'. Border and Transborder Armed Actions (Nicaragua v. Honduras), (Jurisdiction and Admissibility, Judgment) 69 ICJ Reports 1988, para. 94. Equally, when speaking, for instance, of the principle of sovereign equality, it is not hard to see its political, rather than legal nature. Although it shapes the political underpinnings of the international legal order, it requires translation into pre-emptive legal norms that provide a basis for the specific legal rights and obligations that stem from it, such as, for instance, norms pertaining to jurisdictional immunities. That the principle of sovereign equality is not per se a normative legal principle may sound, to an international lawyer's ears, as heresy. Yet it is important to keep in mind that this is by no means a unique feature of international law or for that matter any law: characterising principles such as sovereign equality do give rise to specific legal norms that outline what sovereign equality actually means, normatively, but they do not in themselves have a legal nature. I elaborate on this in the next section.

63 Corfu Channel Case (UK v. Albania) (Merits) (1949) ICJ Reports 4, 22.

${ }^{64}$ E.g., Costa (2013); Düwell (2014); McCrudden (2008). See, however, a critique of the 'legal expropriation' of human dignity in Riley (2019).

65 See, for a general overview, Larsen et al. (2012).

66 Collins (2007); Gundling (1990); Brown Weiss (1990).
} 
the international law of development equity in general is treated as 'the basic principle of international development law' because 'it serves to resolve the contradictions between simultaneous demands for economic independence and for organized mutual aid, for equality in preferential treatment, for common benefit and the renunciation of reciprocity on the part of developing countries' ${ }^{67}$ All these conceptshumanity, dignity, equity, etc.- - represent moral values which international law must protect. It is common to speak of values as principles when we turn them into practical reasons: 68 "the word "principle" is sometimes used to assert an ultimate value or to assert that such a value is a reason for action'. ${ }^{69}$

If we now go back to solidarity, it might be tempting to say that solidarity is a principle because it has the same sort of intrinsic moral value as human dignity, equity, humanity, etc. Acting out of solidarity, from this point of view, is already fulfilling a moral duty which is an end in itself. As Adam Cureton puts it, 'the social moral rules that hold us in solidarity are often valuable for their own sake [...], more precisely, they are non-derivatively valuable in virtue of being a constitutive part of a relationship that is valuable as an end' ${ }^{70}$ This idea comes very close to one of the first formulations of solidarity in international law, when Emer de Vattel wrote:

The offices of humanity are those succours, those duties, to which men are reciprocally obliged as men, that is, as social beings which necessarily stand in need of a mutual assistance for their preservation, for their happiness, and for living in a manner conformable to their nature. ${ }^{71}$

This concept, that we owe duties to each other by the mere fact that we live in a society, reflects, according to de Vattel, 'the general principle' and 'the eternal and immutable law of nature' which reads that: 'One state owes to another state whatever it owes to itself, as far as this other stands in real need of its assistance, and the latter can grant it without neglecting the duties it owes to itself. ${ }^{, 72}$

Without a doubt, people are under a moral obligation to show solidarity, in a sense that it is a valid moral demand to require someone to do something out of solidarity, and it is therefore morally permissible to hold someone accountable for not

\footnotetext{
67 Bulajić (1993), p. 50.

68 The way I use the concept of 'practical reasons' or 'reasons for action' is based on Joseph Raz, once again. He defines a reason for action as 'a consideration that renders its [i.e., action's] choice intelligible, and counts in its favor'. Raz (2006), p. 1006.

69 Raz (1999), p. 49.

70 Cureton (2012), p. 692.

71 de Vattel (1758), p. 257. 'Les Offices d'humanité font ces fécours, ces devoirs, auxquels les hommes font obligés les uns envers les autres en qualité d'hommes, c'eft-à-dire en qualité d'êtres faits pour vivre en fociété, qui ont néceffairement befoin d'une affiftance mutuelle, pour fe conferver, pour être heuruex \& pour vivre d'une manière convenable à leur nature'. The English translation is given by: de Vattel (1759).

72 de Vattel (1758), pp. 258-259: 'Une Etat doit à tout autre Etat ce qu'il fe doit à foi-même, autant que cet autre a un véritable befoin de fon fécours, \& qu'il peut le lui accorder fans négliger fes devoirs envers foi-même.'
} 
showing solidarity. ${ }^{73}$ Without going into detail pertaining to the status of solidarity as a moral reason, it suffices to say that I do not deny that solidarity may, for some people, be a strong non-instrumental moral reason to do something. Yet from how the idea of solidarity is typically constructed, especially in international legal scholarship and practice, it seems that it usually makes sense and is valuable when used as a practical reason in order to secure more fundamental reasons, such as humanity, human dignity, or social cohesion. This brings it closer to a moral principle, rather than to a moral value, although, as already mentioned, the line between the two can be very blurred. ${ }^{74}$

The third category of 'legal principles' looks most promising, then. Solidarity, it seems, is labelled as a 'principle of international law' in the sense that it provides for some critical moral and political normative foundations for the international legal order. This group of principles, however, is the most theoretically challenging, as it unites principles which are fundamentally important for international law in a normative way, but which, at the same time, are not normative in a legal sense. This ascertainment brings us back to the initial jurisprudential problem that surrounds the legal normative implications of such principles as solidarity, sustainable development, and, to a large extent, more 'traditional' ideas of the Rule of Law, democracy, and human rights, which Anne Peters qualifies as 'value-driven organizing principles of constitutional government'. ${ }^{75}$ It is remarkable that Anne Peters uses this particular language for these principles, which resonates with Rüdiger Wolfrum's characteristic of solidarity as a 'structural' principle of international law. Even though in international legal scholarship we may routinely attribute a legal status to these principles, the language used when we talk about them suggests that they perform their normative function at a different, non-legal level.

In order to see what kind of relations bind solidarity and similar 'structural' or 'organising' principles of international law and international legal normativity, we must investigate what actually makes normativity legal and what functions legality performs with regard to these and other non-legal principles and values. If solidarity is such a non-legally normative principle, how can we account for its status in law?

\footnotetext{
73 I am following the structure of moral obligation and moral reason as offered by Stephen Darwall (2006).

74 On a separate note, I do believe that it is more consistent to argue that solidarity is not deontologically normative, such as, for instance, human dignity. This point is convincingly elaborated by Kurt Bayertz: it is quite difficult to justify solidarity as a moral obligation because it calls for positive action, whereas moral obligations are typically grounded in the paradigm of warding off dangers occurring in social co-existence and because of this they are generally negative or at least restrictive. As a consequence, 'manifestations of solidarity may be morally commendable, but they cannot be made [morally] binding'. Besides, whereas moral obligations are universal in the sense that they cannot contain any references to contingent characteristics, this is typically what solidarity assumes. If we try to claim that solidarity does not discriminate and we must therefore show solidarity with all the people in the world, it is unclear how it would then differ from the categorical imperative or other similar moral norm. Bayertz (1999).

75 Peters (2006), p. 601.
} 


\section{Solidarity, Legality, and the Authority of International Law}

In the previous section, I argued that we need to differentiate between different uses of the concept of a 'legal principle' or a 'principle of law'. I have also claimed that solidarity belongs to the kind of principles that, although relevant for international law and possibly with a normative function, are not legally normative. This reflects the general disposition towards solidarity in international legal scholarship, which we saw in the second section: it is a legal concept and a legally relevant principle, but one which, nevertheless, cannot be undoubtedly said to generate legal obligations, that is, it is hardly legally binding. How can we then solve this conundrum of solidarity? Is there a way to account for such principles, which are, on the one hand, critically important for law, but on the other hand are not in themselves legal, without necessarily ruining the distinction between law and non-law?

It is important to stress that when we speak about the legality of some norm or principle, this typically entails that we trace it back to some source(s) of (international) law. We may label this view 'source-based legality'. In this view, legality is tantamount to legal validity, that is, law is something that we can identify by using formal criteria of origin. ${ }^{76}$ What is important, however, is that not everything which is legally valid is the law of a specific system. It is possible to have a legally valid norm, i.e. a norm which relevant actors are bound to apply when solving legal cases, that does not belong to the legal order in question. In other words, what courts and other officials are bound to apply because law authorises them to do so, is not tantamount to the law of the particular legal order in general. ${ }^{77} \mathrm{~A}$ classic example in this regard is that courts in domestic legal systems are often bound to apply the law of another country. The law of another country, in this situation, is legally valid in the sense that courts are bound to apply it, but it is not a part of the legal order in which it is applied. ${ }^{78}$ In the same way, for instance, the International Criminal Court, in certain circumstances, may make use of appropriate domestic criminal law when solving cases, ${ }^{79}$ but this does not make it a part of international criminal law. The same holds true for moral standards: courts may be obligated by the law to

\footnotetext{
76 See, generally, on the application of this conception of legality to international law, d'Aspremont (2011).

77 See Shapiro (1998), pp. 505-207. For the difference between legal validity and legality, see also Raz (1999), pp. 127-129; Raz (2009), pp. 146-159.

78 Such matters are typically regulated within a private international law framework that sets up principles of choices of law according to which courts may be authorised or required to apply the law of another country in their domestic jurisdiction. See, for instance, the conventions adopted within the Hague Conference on Private International Law: https://www.hcch.net/en/instruments/conventions. Accessed 13 December 2021.

79 Rome Statute of the International Criminal Court (adopted 17 July 1998) 2187 UNTS 3, Art. 21(1)(c) which reads that the Court shall apply, secondary to its Statute, Elements of Crimes, and Rules of Procedure, as well as applicable treaties and principles of international law, 'general principles of law derived by the Court from national laws of legal systems of the world including, as appropriate, the national laws of States that would normally exercise jurisdiction over the crime, provided that those principles are not inconsistent with this Statute and with international law and internationally recognized norms and standards.' Emphasis added.
} 
apply moral standards (e.g., reasonableness, fairness, etc.), which makes these moral standards legally valid, but does not make them into law. ${ }^{80}$

However, for many moral standards, to which we may find direct or indirect references in law, it is not at all given that they are even legally valid, let alone that they are legal. I mean, of course, those moral or political values and principles which inspire certain legal documents and are mentioned in preambles or figure in travaux préparatoires. Such moral or political principles and values, though recognised by law as relevant for, e.g., the interpretation of legal provisions, are not necessarily legally valid in themselves, that is, courts and other relevant actors are not legally bound to apply them per se. These are precisely the third and the fourth categories of 'principles' mentioned in the previous section. Solidarity is one of such principles, since it is beyond doubt that it serves as an inspirational ideal for many international legal regimes, but at the same time it creates no direct legal obligations for states. It creates a very peculiar theoretical puzzle, as it is unclear how such principles correlate with international legal normativity.

Since, as we just saw, legal validity is not a sufficient criterion to qualify some norm or principle as legal, it is possible to suggest that legality should also be approached functionally. In this view, something is legal not necessarily (or only) because it comes from a valid source, but because it performs a specific function. We have law because it secures benefits that would not be possible without it. Most importantly, law offers a special normative technique which is not available for other normative systems such as, for instance, morality or politics. Law, by establishing general standards of conduct irrespective of individual preferences and moral beliefs, allows us to bypass the moral and political disagreements that people have. This is precisely why, if we accept that a moral standard is a part of law (like saying that solidarity is a legal principle), we make it impossible for law to make a practical difference in performing its function. If we have the law because it allows us to bypass moral disagreements by establishing general rules of conduct, it is detrimental for the very function of the law to apply as legal those moral standards which cause the disagreements we wanted to prevent by having the law in the first place. ${ }^{81}$

Thus, we may say that solidarity is a valid moral principle which makes it morally commendable to assist those who suffer from need or require our assistance, that is, to refer back to de Vattel, when we owe to another whatever we owe to ourselves. Or, even more so, we may say that solidarity requires us to contribute to communal interests by performing actions in favour of the community even when this goes against our individual interests. However, it is not difficult to see that even though we may recognise the validity of this moral principle, it does not necessarily mean that everyone does. That we may believe that contributing to communal interests is the morally right thing to do, does not mean that our neighbour thinks so. He may believe, as probably many people do, that it is far more important to secure

\footnotetext{
${ }^{80}$ E.g., if the ICJ will ever be called upon to solve a dispute in accordance with Art. 38(2) of its Statute, that is, ex aequo et bono, this would not mean that the moral standards applied by the Court in such a context become legal, even though the Court is legally authorised (by its Statute) to apply them.

81 This argument is very much influenced by Scott Shapiro's view on the function of legality in Shapiro (2011), p. 214.
} 
individual liberty and prosperity, which in themselves ground valid moral principles. We are, then, in disagreement. It may be practically impossible to overcome this disagreement by simply trying to convince our neighbour to act out of solidarity (he is quite stubborn and frankly has the right to have a moral position of his own). This may become even more difficult when solidarity is treated as a practical reason at the level of a society at large, or even more so the global level. Should a state assist the population of another state suffering from a civil war, or should it instead stick to a neutral position? Should a state admit a large number of refugees, or should it keep its borders closed to prevent political volatility? Should a state introduce measures that would limit atmospheric pollution, or should it strive for maximising economic growth? All these kinds of dilemmas are in essence examples of complex practical deliberations, when relevant actors must adequately weigh all appropriate reasons, solidarity being one of these. And what is essential for such dilemmas is that they necessarily involve disagreement. Exactly because we have disagreements such as these, there is a need for a special normative technique that allows us to create rules of conduct which enable us to achieve the aims we have without necessarily resolving this disagreement.

Law, then, makes it possible to obligate everyone to do something even if this action is not morally justified or required by our personal or collective moral beliefs, or, as Scott Shapiro phrases it:

By settling matters in favor of the directed action, law cuts down on deliberation and bargaining costs and compensates for cognitive incapacities and informational asymmetries, thereby enabling community members to achieve goals and realize values that would otherwise be beyond their grasp. ${ }^{82}$

That is, the value of having law is precisely that it enables us to simply point at a binding legal rule instead of convincing someone to act in a certain way because of the moral or political merits of such an action. This entails the pre-emptive force of law as a matter of practical deliberations: 'the fact that an authority requires performance of an action is a reason for its performance which is not to be added to all other relevant reasons when assessing what to do, but should exclude and take the place of some of them'. ${ }^{83}$

This idea that law by claiming practical authority pre-empts reasons for action allows us to see that such moral and political values and principles like solidarity, sustainable development, the rule of law, democracy, and so on, are relevant for law and determine its content as long as the law pre-empts them. Pre-emption means that law replaces the moral and political reasons for action on which we may disagree with a shared normative standard. This by no means entails that, once we have this standard, we no longer disagree. We do, and it is an essential part of political life to debate social issues even when, or one might say, exactly because, they are legally regulated.

The mechanism of normative pre-emption entails the introduction of legal rules which legally obligate us to perform some actions (or to abstain from performing

\footnotetext{
82 Shapiro (2011), p. 247.

83 Raz (1986), p. 46.
} 
certain actions), regardless of whether these actions are independently justified by moral or political considerations. As a result, it is these legal rules that become reasons for a desirable action, and not necessarily the underlying considerations, which may be shared by some people, but not shared by others. For example, it may be morally and politically desirable if members of a certain community contributed some part of their wealth to solving general problems the community may be faced with. Some members of this community may feel deontologically obliged to do so, as they believe it is the right thing to do. But it cannot be taken for granted that all members of our hypothetical community share the same high moral standard (remember our neighbour?). The simplest solution would be to introduce a taxation system-historically the first system of solidarity. What practical difference does it make? Because paying taxes is now a legal obligation, it no longer depends on moral deliberations, and even if one disagrees on whether an existing taxation system is fair or what activities the money collected is spent on, it does not change the fact that one must pay one's taxes. Consequently, even though the motivation of solidarity may lie in the background of tax law, it is not because of solidarity that we pay taxes, it is because the law obligates us to do so. We no longer morally ought to financially contribute to our community, we legally must do so.

It is essential to observe that law's pre-emptive force may come in degrees. Law may be more or less successful in replacing moral or political reasons for action, and this also applies to international law. 'Law's legitimate authority is not necessarily as general as the law claims it is', ${ }^{84}$ which necessarily entails that when law lacks authority in some domains where it claims to have it, it is all but natural for subjects to fall back on the underlying reasons. ${ }^{85}$ In international law, where practical authority is typically not mediated by formal institutions, it may take time to achieve the degree of pre-emptive force which replaces underlying reasons in practical deliberations. $^{86}$

Thus, even though international law may claim to provide for legal rules and procedures which obligate states to act in a way they would have acted anyway were they acting out of sheer solidarity, this may not necessarily be the case. It is often claimed, for instance, that the system of collective security established after World War II is a manifestation of international solidarity. ${ }^{87}$ And yet, the proponents of humanitarian intervention or the doctrine of the responsibility to protect, which enjoy a doubtful legal status, often justify them by considerations of solidarity. ${ }^{88}$

\footnotetext{
84 Besson (2008), p. 354.

85 But this also has another implication. It is possible that law does not claim authority in domains where it probably should, and this is precisely what enables the interpretative power of principles in avoiding non liquet situations. The use of principles for filling up normative gaps is essentially a reconstruction of the pre-emptive reasoning of one domain in another domain, based on the assumption that these two domains share the same moral/political reasons which are to be legally pre-empted.

86 A good illustration of this claim is the slow shift of paradigm regarding the use of force in international law initiated by the Kellogg-Briand Pact of 1928. It took almost 20 years for the new legal norm of the prohibition of aggressive war to pre-empt the political and moral reasons existing at that time. See, on the history of the Pact and its growing pre-emptive force: Hathaway and Shapiro (2017).

87 Koroma (2012), pp. 104-105; Slaughter (2005), pp. 622-627; Wolfrum (2009), pp. 11-14.

88 Arnison (1993); de Chazournes (2010); Wolfrum (2009), pp. 17-19.
} 
This kind of debate shows that when (international) law claims to pre-empt certain reasons but fails to do so at least in some concrete circumstances, these underlying reasons become essential for practical deliberations. To put it in different terms, in an international legal order that truly appreciates the principle of solidarity, one does not have to justify one's legal position by referring to solidarity, for one has pre-emptive legal rules to invoke.

This is why Lorenzo Casini is correct in his statement that 'solidarity can acquire the status of legal principle only when it loses its "altruistic" character: if [so], then States may use this principle in order to establish mutual obligations aimed at reducing risks and uncertainty'. ${ }^{89}$ Or, as Sergio Dellavalle puts in his excellent analysis of solidarity and practical rationality, 'sovereign actors have an obligation of solidarity only if they deploy, in their actions, a practical use of reason' that assumes the sort of normative structure that I have tried to delineate here. ${ }^{90}$ Indeed so, solidarity only makes sense legally if its moral core is pre-empted by legal rules. The only thing is that, if this happens, solidarity does not need to be a legal principle, for its legal representation will boil down to specific rules of obligation. Solidarity is only relevant for law as long as legal rules mediate its moral implications. ${ }^{91}$

From all this it follows that, paradoxically, the central argument used to qualify solidarity as a principle of international law, namely that the idea of solidarity is reflected in many different regimes of international law, is essentially the main reason why it is not a principle of international law. That states account for considerations of solidarity in international environmental law, international human rights law, international law on the use of force, international trade law, international law of development, and so on, shows that solidarity requires legal pre-emption in order to legally bind states. For this reason, solidarity will never (and in fact does not have to) become a legally binding principle of international law, because its role in international legal normativity is drastically different. Together with other moral and political principles, solidarity grounds the legitimacy of the international legal order, which is essential for the practical authority of international law. When law fails to account for relevant moral and political reasons and does not, in such a way, perform its function of bypassing the disagreements we may have about these reasons, its authority may vanish very quickly. The principle of solidarity, therefore, is amongst those ideas that ground international law's authority by legitimising its rules, procedures, and institutions. Hence, it is essential that international law keeps

\footnotetext{
${ }^{89}$ Casini (2014), p. 108. A very similar argument is advanced by Andrea Sangiovanni in his analysis of solidarity under EU law in Sangiovanni (2013).

90 Dellavalle (2015), p. 396. The actual argument Dellavalle develops in his piece is rather complex for being eligible for a short summary. He writes that 'universalism, consent-orientation, as well as a postmetaphysical and deontological attitude are the inescapable conditions under which the use of reason by a sovereign actor can lead to the determination of solidarity as an obligation and as a compelling legal norm'. He claims that communicative rationality allows to enable the legal normativity of solidarity, but all the prerequisites that he lists do assume an existence of a normative framework in which practical reasons become elevated above the level of disagreement. That said, I see our approaches to be complementary, although coming from different ends.

91 Jürgen Habermas skilfully used this argument in his advocacy for a European constitution, a project that, however, never came to be. He claims that one of the central tasks of any constitution is to create, through democratic citizenship, 'legally mediated solidarity between strangers'. Habermas (2001), p. 16.
} 
embracing the principle of solidarity by strengthening the pre-emptive veil of legal rules.

\section{Conclusions}

'Solidarity is not discovered by reflection but created,' wrote Richard Rorty. ${ }^{92}$ It seems that contemporary international law and international legal scholarship fully embrace this view. Solidarity is something that states, international organisations, and ordinary people may and should shape by their actions. This means, at the very least, that solidarity is a practical reason, not just a fact, and as a reason it exhibits some fundamental moral values which must also underlie international law. This intrinsic normativity of solidarity makes it tempting to treat it as more than just a moral principle, but as a principle of international law.

Such a perspective on solidarity, however altruistic it may be, unfortunately misses the point about the function of (international) law and the way it connects to its moral and political underpinnings. I attempted to show that solidarity is not a principle of international law in any legal sense, but, most importantly, it does not have and should not have characteristics of legality. Solidarity, being a political and moral principle, relates to law in a way that is very similar to other principles of such a kind, like democracy, the rule of law, or fairness. International law is supposed to normatively pre-empt these principles by replacing them, as a matter of legal reasoning, with legal rules. In such a way, international law performs the central function of legality, which is bypassing the moral and political disagreements people may have. By establishing general rules of conduct which are binding irrespective of individual or even collective moral beliefs, international law legally obligates states to act in a way that is justified by motives of solidarity. As a result, it is the rules of international law which become reasons for actions, rather than solidarity as such.

Such a relation between solidarity, and other similar principles, and international legal normativity highlights the nature of international legal authority. On the one hand, international law's authority is legitimised as long as it accounts for such fundamental moral principles, and for this reason it is essential that considerations of solidarity keep penetrating into larger numbers of international legal regimes and branches. On the other hand, normative authority always comes in degrees, and in the case of international law it may take a long time for the underlying moral and political principles to become effectively pre-empted by legal rules. Moreover, when international law fails to account for solidarity in the areas where it is expected or needed, it is all but natural to fall back on solidarity as a practical reason if it is not (effectively) pre-empted. In such a way, in a strongly authoritative international legal order one would not need to resort to moral and political reasons such as solidarity. International law must strive for normative authority which would make the appeal to these reasons redundant.

${ }_{92}$ Rorty (1989), p. xvi. 
Open Access This article is licensed under a Creative Commons Attribution 4.0 International License, which permits use, sharing, adaptation, distribution and reproduction in any medium or format, as long as you give appropriate credit to the original author(s) and the source, provide a link to the Creative Commons licence, and indicate if changes were made. The images or other third party material in this article are included in the article's Creative Commons licence, unless indicated otherwise in a credit line to the material. If material is not included in the article's Creative Commons licence and your intended use is not permitted by statutory regulation or exceeds the permitted use, you will need to obtain permission directly from the copyright holder. To view a copy of this licence, visit http://creativecommons.org/licen ses/by/4.0/.

\section{References}

Alexy R (2000) On the structure of legal principles. Ratio Juris 13:294-304

Alvarez A (1912) La codification du droit international: ses tendances; ses bases. Éditions Internationales, Paris

Arnison ND (1993) International law and non-intervention: when do humanitarian concerns supersede sovereignty? Fletcher Forum of World Affairs 17:199-201

Barcia Trelles C (1927) Francisco Vitoria et l'école moderne du droit international. Recueil des Cours, vol 17. Librairie Hachette, Paris, pp 113-342

Barnidge R (2006) The due diligence principle under international law. Int Commun Law Rev 8:81-121

Bassiouni C (1990) A functional approach to "general principles of international law." Michigan J Int Law 11:768-818

Bayertz K (1999) Four uses of "solidarity.” In: Bayertz K (ed) Solidarity. Kluwer Academic Publishers, Dordrecht, pp 3-28

Besson S (2008) The authority of international law - lifting the state veil. Sydney Law Rev 31:343-380

Bouchez LJ (1973) The freedom of the high seas: a reappraisal. In: Bouchez LJ, Kaijen L (eds) The future of the law of the sea. Springer, Dordrecht, pp 21-50

Brown Weiss E (1990) Our rights and obligations to future generations for the environment. Am J Int Law 84:198-207

Brownlie I (2008) Principles of public international law. Oxford University Press, Oxford

Bulajić M (1993) Principles of International development law: progressive development of the principles of international law relating to the new international economic order. Martinus Nijhoff, Dordrecht

Bull H, Kingsbury B, Roberts A (1992) Introduction: Grotian thought in international relations. In: Bull H, Kingsbury B, Roberts A (eds) Hugo Grotius and international relations. Oxford University Press, Oxford, pp 1-64

Campanelli D (2011) Principle of solidarity. In Max Planck encyclopedia of public international law. https://opil.ouplaw.com/view/https://doi.org/10.1093/law:epil/9780199231690/law-9780199231 690-e2072?rskey=mUxydQ\&result=1\&prd=MPIL. Accessed 1 Apr 2021

Casini L (2014) Solidarity between states in the global legal space. Eur Rev Public Law 26:91-115

Cheng B (2006) General principles of law as applied by international courts and tribunals. Cambridge University Press, Cambridge

Collins LM (2007) Revisiting the doctrine of intergenerational equity in global environmental governance. Dalhousie Law J 30:79-140

Costa JP (2013) Human dignity in the jurisprudence of the European Court of Human Rights. In: McCrudden C (ed) Understanding human dignity. Oxford University Press, Oxford, pp 393-402

Cottier T et al (2017) The principle of proportionality in international law: foundations and variations. J World Invest Trade 18:628-672

Cureton A (2012) Solidarity and social moral rules. Ethical Theory Moral Pract 15:691-706

d'Aspremont J (2011) Formalism and the sources of international law: a theory of the ascertainment of legal rules. Oxford University Press, Oxford

d'Aspremont J (2018) What was not meant to be: general principles of law as a source of international law. In: Mazzeschi RP, De Sena P (eds) Global justice, human rights and the modernization of international law. Springer, Cham, pp 163-184

Darwall SL (2006) The Second-person standpoint: morality, respect, and accountability. Harvard University Press, Cambridge, MA 
de Vattel E (1758) Le droit de gens, ou principes de la loi naturelle: Appliqués à la conduit et aux affairs des Nations et des Souverains, vol 1. Leide

de Vattel E (1759) The law of nations; or, principles of the law of nature: applied to the conduct and affairs of nations and sovereigns, vol. 1. London

De Chazournes LB (2010) Responsibility to protect: reflecting solidarity? In: Wolfrum R, Kojima C (eds) Solidarity: a structural principle of international law. Springer, Heidelberg, pp 93-110

Delbrück J (2012) The international obligation to cooperate-an empty shell or a hard law principle of international law? - a critical look at a much debated paradigm of modern international law. In: Hestermeyer H, Wolfrum R (eds) Coexistence, cooperation and solidarity: Liber Amicorum Rüdiger Wolfrum. Martinus Nijhoff, Leiden, pp 3-16

Dellavalle S (2015) On sovereignty, legitimacy, and solidarity or: how can a solidaristic idea of legitimate sovereignty be justified? Theoret Inquiries Law 16:367-398

Duguit L (1908) Le droit social, le droit individuel et la transformation de l'état. Librairie Félix Alcan, Paris

Durkheim É (1933) The division of labour in society. Macmillan Company, New York

Düwell M (2014) Human dignity: concepts, discussions, philosophical perspectives. In: Düwell M et al (eds) The Cambridge handbook of human dignity. Cambridge University Press, Cambridge, pp 23-50

Dworkin R (1977) Taking rights seriously. Duckworth, London

Dworkin R (1986) Law's empire. Belknap Press, Cambridge, MA

Gaja G (2013) General principles of law. In: Max Planck encyclopedia of public international law. https://opil.ouplaw.com/view/https://doi.org/10.1093/law:epil/9780199231690/law-9780199231 690-e1410?prd=MPIL. Accessed 1 Apr 2021

Gundling L (1990) Our responsibility to future generations. Am J Int Law 84:207-212

Habermas J (2001) Why Europe needs a constitution. New Left Rev 11:5-26

Hart HLA (1994) The concept of law. Oxford University Press, Oxford

Hathaway O, Shapiro SJ (2017) The internationalists: how a radical plan to outlaw war remade the world. Simon \& Schuster, New York

Hayward J (1959) Solidarity: the social history of an idea in nineteenth century France. Int Rev Soc Hist 4:261-284

Hayward J (1961) The official social philosophy of the French third republic: Léon Bourgeois and solidarism. Int Rev Soc Hist 6:19-48

Jamnejad M, Wood M (2009) The principle of non-intervention. Leiden J Int Law 22:345-381

Kojima C, Menzel K (2009) Symposium on solidarity as a structural principle of international law, Max Planck Institute for Comparative Public Law and International Law, 29 October 2008. Verfassung in Recht Und Übersee 42:585-588

Koroma A (2012) Solidarity: evidence of an emerging international legal principle. In: Hestermeyer $\mathrm{H}$, Wolfrum R (eds) Coexistence, Cooperation and solidarity: liber amicorum Rüdiger Wolfrum. Martinus Nijhoff, Leiden, pp 103-129

Koskenniemi M (2002a) Solidarity measures: state responsibility as a new international order? $\mathrm{Br}$ Yearbook Int Law 72:337-356

Koskenniemi M (2002b) The Gentle civilizer of nations: the rise and fall of international law, 18701960. Cambridge University Press, Cambridge

Kotzur M (2017) Solidarity as a legal concept. In: Grimmel A, My Giang S (eds) Solidarity in the European Union: a fundamental value in crisis. Springer, New York, pp 37-45

Kreß C (2015) The International Court of Justice and the 'principle of non-use of force.' In: Weller M et al (eds) The Oxford handbook of the use of force in international law. Oxford University Press, Oxford, pp 561-596

Larsen KM et al (eds) (2012) Searching for a 'Principle of humanity' in international humanitarian law. Cambridge University Press, Cambridge

MacDonald R (1996) Solidarity in the practice and discourse of public international law. Pace Int Law Rev 8:259-302

McCrudden C (2008) Human dignity and judicial interpretation of human rights. Eur J Int Law 19:655-724

Nyst C (2012) Solidarity in a disaggregated world. Universal jurisdiction and the evolution of sovereignty. J Int Law Int Relations 8:36-61

Peters A (2006) Compensatory Constitutionalism: the function and potential of fundamental international norms and structures. Leiden J Inte Law 19:579-610 
Rangel V (2012) The solidarity principle, Francisco De Vitoria and the protection of indigenous peoples. In: Hestermeyer H, Wolfrum R (eds) Coexistence, cooperation and solidarity: liber amicorum Rüdiger Wolfrum. Martinus Nijhoff, Leiden, pp 103-129

Raz J (1972) Legal principles and the limits of law. Yale Law J 81:823-854

Raz J (1986) The morality of freedom. Oxford University Press, Oxford

Raz J (1999) Practical reason and norms. Oxford University Press, New York

Raz J (2006) The problem of authority: revisiting the service conception. Minnesota Law Rev 90:1003-1044

Raz J (2009) The authority of law: essays on law and morality. Oxford University Press, New York

Riley S (2019) Human dignity as a sui generis principle. Ratio Juris 32:439-454

Rorty R (1989) Contingency, irony, and solidarity. Cambridge University Press, Cambridge

Sangiovanni A (2013) Solidarity in the European Union. Oxf J Leg Stud 33:213-241

Scelle G (1935) Théorie du gouvernement international. Annuaire de l'Institute International de Droit Public 41-112

Shapiro SJ (1998) On Hart's Way out. Leg Theory 4:469-507

Shapiro SJ (2007) The 'Hart-Dworkin' debate: a short guide for the perplexed. In: Ripstein A (ed) Ronald Dworkin. Cambridge University Press, Cambridge, pp 22-55

Shapiro SJ (2011) Legality. Harvard University Press, Cambridge, MA

Simma B (1994) From bilateralism to community interest in international law. Recueil des Cours: Collected Courses of the Hague Academy of International Law, vol 250. Martinus Nijhoff, The Hague, pp 217-384

Slaughter A-M (2005) Security, solidarity, and sovereignty: the grand themes of UN reform. Am J Int Law 99:619-631

Thirlway H (2019) The sources of international law. Oxford University Press, Oxford

Tzimas T (2019) Solidarity as a Principle of international law: its application in consensual intervention. Groningen J Int Law 6:333-359

Van Boven T (2011) The right to peace as an emerging solidarity right. In: Rieter E, Waele H (eds) Evolving principles of international law: studies in honour of Karel C. Wellens. Martinus Nijhoff, Boston, pp 137-147

Waldron J (2019) Non-normative principles. NYU School of Law, Public Law Research Paper No. 19-36. https://papers.ssrn.com/sol3/papers.cfm?abstract_id=3400296. Accessed 1 Apr 2021

Wellens K (2005) Solidarity as a constitutional principle: its expanding role and inherent limitations. In: MacDonald R, Johnston D (eds) Towards world constitutionalism: issues in the legal ordering of the world community. Martinus Nijhoff, Leiden, pp 775-807

Wellens K (2010) Revisiting solidarity as a (re-)emerging constitutional principle: some further reflections. In: Wolfrum R, Kojima C (eds) Solidarity: a structural principle of international law. Springer, Heidelberg, pp 3-38

Wellman C (2000) Solidarity, the individual and human rights. Hum Rights Q 22:639-657

Williams A (2009) Solidarity, justice and climate change Law. Melbourne J Int Law 10:493-508

Wolfrum R (2009) Solidarity Amongst states: an emerging structural principle of international law. Indian J Int Law 49:8-20

Wolfrum R (2010a) Concluding remarks. In: Wolfrum R, Kojima C (eds) Solidarity: a structural principle of international law. Springer, Heidelberg, pp 225-228

Wolfrum R (2010b) International law of cooperation. In: Max Planck Encyclopedia of Public International Law. https://opil.ouplaw.com/view/https://doi.org/10.1093/law:epil/9780199231690/law9780199231690-e1427?rskey=14ZFX1\&result=1\&prd=MPIL. Accessed 1 Apr 2021

Wolfrum R, Kojima C (eds) (2010) Solidarity: a structural principle of international law. Springer, Heidelberg

Wolfrum R (2013) Solidarity. In: Shelton D (ed) The Oxford handbook of international human rights law. Oxford University Press, Oxford, pp 402-418

Publisher's Note Springer Nature remains neutral with regard to jurisdictional claims in published maps and institutional affiliations. 